\title{
Globalization and Corporate Governance Mechanism, Engine of Change
}

\author{
Martha Coleman (Corresponding author) \\ School of Finance and Economics, Jiangsu University, Zhengjian, China \\ School of Business, Takoradi Technical University, Ghana \\ E-mail: naadjoacole@yahoo.com
}

Professor Mengyun Wu

School of Finance and Economics, Jiangsu University, Zhengjian, China

E-mail: mewu@ujs.edu.cn

Justices Mark Baidoo

School of Business, Takoradi Technical University, Ghana

E-mail: badupaa@yahoo.com

Received: December 17, 2019

Accepted: January 8, 2020 Published: February 8, 2020

doi:10.5296/ber.v10i1.16048

URL: https://doi.org/10.5296/ber.v10i1.16048

\begin{abstract}
This study is undertaking to investigate the effect of the various dimensions of globalization on corporate governance sub-indices of listed companies in Nigeria and Ghana. The study used a panel data of nonfinancial companies listed on Nigeria and Ghana stock exchange for the period 2012 - 2016 with total observation of 510. Using KOF Globalization Index which entails composite index measuring economic, social and political dimension of globalization. It was discovered that all the dimensions of globalization influence the corporate governance mechanisms. The impact of globalization on sectors of the economies clearly shows that West African countries have been greatly influenced by globalization for resource utilization and improvement in living standard. Although poverty still seems to be high, it is of no doubt that globalization has sharpened the economic efficiency and sustainable growth and financial stability base on continuous improvement on corporate governance mechanisms for the achievement of better economic stability.
\end{abstract}


Keywords: Corporate Governance, Economic globalization, Social globalization, Political globalization, West Africa

\section{Introduction}

Most research work focus on corporate governance index and its influence on firm's performance Shawtari et al., 2016; Bhagat \& Bolton (2019); Pillai \& Al-malkawi (2017) only few research focused on the effect of other drivers of corporate governance (Min \& Smyth, 2013). Globalization has been one of the instruments used to connect the Africa continent to the rest of the world. From the time of colonization to liberation of the African continent, various transformations have taken place to position it to utilize resources. Africa continent is endowed with so many natural resources which fully and efficiently utilized position the continent as the wealthiest of all continents. Neo-liberal economists perceive globalization as the "integration of markets for goods, services and factors of production" (Wolf, 2003), and "the integration of national economies and the development of international markets" (Bordo, Eichengreen, \& Irwin, 1999). Mohamad (2002) described globalization as in theory supposed to benefit all nations and continents, the reality proof different, the concept was crafted by the advance countries (developed countries) for their multinational companies (MNC) for the removal of barriers placed in place by developing countries to promote their economy. Each global economy regulators have different mission: WTO - fostering trade; IMF - capitalizing on financial stability, and WB- encouraging development. However, there is an imprecise distinction in the activities undertaking by these global economy regulators (Friedrichs \& Friedrichs, 2002). They are mostly controlled by Northern powers (Chang, 2007) and their attempt to incorporate developing economies into the globalized economy have been indicted as following a plan of modernism and neoliberal economics (Friedrichs \& Friedrichs, 2002; Nissanke \& Thorbecke, 2006; Scholte, 2002). There in complexity in globalization than anticipated (Martens \& Raza, 2010) and it hinders deterministic, linear, functionalist forms of development (Robertson, 1990).

Many Sub-Saharan African countries have experienced major economic transformation through Economic globalization (Asiedu, 2004; Berry, 2009; Ruparelia, 2016). From the perspective of foreign investors, these reforms need more advancement (Asiedu, 2004; Ruparelia, 2016). Therefore, for the developing economies to attract foreign investors and experience massive economic transformation there must be good governance policies, both at the country and company level. The genesis of corporate governance can be traced back to the work of Berle and Means (1932) who noticed that once contemporary corporation grows to a very large size, separate control system different from direct ownership must be established. This observation generated interest in the behavioral aspect of enterprises. Governance, coming from a Latin 'Gubernare' means to direct (Cadbury, 1992) implies being "wise and responsible," when applied to companies, will imply undertaking the right action that favors all stakeholders. Corporate governance gained eminence in the 1980s and 90s because of stock market crashes and general corporate failure across the world (Dagli, Eyuboglu, \& Ayadin, 2012). Cutting \& Kouzim (2000) observed that for corporations to obtain right direction stewardship to be effective on the part of managers there must be effective board (Gompers, Ishii, \& Metrick, 2003). Business crises and crashes experienced 
in the developed countries is not different from companies' failure in the developing countries today. Mehlum et al. (2006) claim that these economies typically have poor governance systems, weak institutions inadequate skills, expertise and methods needed to manage the resources. According to IIAG Report (2018) out of 14 sub-categories of governance that compose the IIAG, only three have seen large African average decline over the decade: Personal Safety (-6.1), Business Environment (-4.9) and National Security (-4.4). Over the last decade, which has been one of economic growth for the continent, Africa's average progress in Sustainable Economic Opportunity for its citizens has been nearly non-existent. The 2017 Sustainable Economic Opportunity African average score (44.8) is barely higher than ten years ago in 2008 (only +0.1 points, an increase of only $0.2 \%$ ) whilst Africa's GDP has grown by $39.7 \%$ over the same period. Almost half (43.2\%) of Africa's citizens live in one of the 25 countries where Sustainable Economic Opportunity has declined in the last ten years. This has led to the collapse of most public and private enterprises and has rendered many jobless.

This research work is undertaking to investigate the effect of the various dimensions of globalization on the corporate governance sub-indices of listed companies in Nigeria and Ghana. Base on the principles of corporate governance by OECD (2015) corporate governance was instituted to help policymakers of various countries to evaluate and well improve the legal, regulatory, and institutional framework for firm level governance, in respect of supporting economic efficiency, sustainable growth and financial stability. This will be realized through the provision of right incentives for board of directors and various stakeholders to perform their role effectively. It is thus expected that companies which adopt recommendations of the Governance Code are likely to enhance their corporate performance (Akbar, Poletti-hughes, El-faitouri, Zulfiqar, \& Shah, 2016). From the analysis, it was discovered that all the dimensions of globalization influence the corporate governance sub-indices (board structure, board procedure and board disclosure). The impact of globalization on sectors of the economies clearly shows that African continent has been greatly influenced by globalization for resource utilization and improvement in the living standard of citizens. Although poverty still seems to be high in some regions in Africa, it is of no doubt that globalization has sharpened the economic efficiency and sustainable growth and financial stability base on continuous improvement on corporate governance mechanisms for the achievement of better economic stability.

\section{Literature Review}

\subsection{Globalization}

Globalization could be seen as an aggregate concept that refers to growing global connections through nation to nation financial flows. Globalization contributes to the economic growth of most countries through the movement of financial assets, capital and financial corporations from the domestic country to other countries. In most cases are the developed countries investing in developing countries. This directly/indirectly sharpens the overall governance of country and corporate governance of firms in the receiving end. The term globalization by Lehman (2005) refers to the economic consequences of internationalization which enables 
expansion of trade and commerce between countries. Globalization seeks to remove all national barriers to the free movement of international capital and the process is accelerated and facilitated by the supersonic transformation in information technology. It could therefore be said that globalization is mainly a phenomenon of capital mobility, through its two prongs which are foreign direct investment and international portfolio flow (Jhingan, 2010, pp. 43). Globalization could, in principle, help to raise the growth rate in developing countries through a number of channels. Some of these directly affect the determinants of economic growth (augmentation of domestic savings, reduction in the cost of capital, transfer of technology from advanced to developing countries, and development of domestic financial sectors). Indirect channels, which in some cases could be even more important than the direct ones, include increased production specialization due to better risk management, and improvements in both macroeconomic policies and institutions induced by the competitive pressures or the "discipline effect" of globalization (Eswar et al., 2003).

Globalization has been described by Gallhofer and Haslam (2006) \& Crawford (2017) as a dynamic phenomenon that has supported the spread of international organizations operating at a level beyond individual state control. Supra-state organizations take the form of: for-profit Transnational Companies (TNCs); international governmental organization (IGOs), for example United Nations organizations and committees of the European Parliament; and International Non-Governmental Organizations (INGOs), encompassing diverse organizations such as the International Accounting Standard Board (IASB), and international charities. Contemporary international accounting emphasizes measuring and communicating the economic consequences of international business to "foster trust, growth and long-term financial stability in the global economy" (IFRS Foundation, 2015a), supporting neoliberal capitalism (Crawford, 2017). At the other side of the coin, in many developing economies, globalization has rather increased poverty, there increase in inequality, and had detrimental environmental impacts, prompting many academics, commentators and poverty reduction and environmental activists to seek change (Hopper, 2017).

\subsection{Globalization and Corporate Governance in Africa}

Globalization systems change relations between international capital and nation-states, which raises major questions (Murphy, 2008). The institution of Regulatory institutions in developing countries influence governance at firm level and transparency which is part of the recommendations of Report on the Observance of Standards (ROSC) (Hopper et al., 2016). The continued advocacy of the World Bank (WB) and the International Monetary Fund (IMF) for New Public Management (NPM) in government departments seeks a shift from input and process accountability (bureaucracy, rules, regulations) to results (appraising civil servants against key performance indicators); granting local managers greater discretion over means (subject to budget constraints); tendering out services; reconstructing civil service organizations around programs; and improved reporting, accountability and monitoring mechanisms (Awio, Lawrence, \& Northcott, 2007). Countries can only enjoy the full benefits of the global capital market, if corporate governance mechanisms must be well instituted, well understood across borders and adhere to internationally accepted principles. Economic growth greatly depends on the formal instituted corporation, therefore regulatory and legal 
environment influences the performance of these corporations which in tend affect economic outcomes (OECD, 2015).

Globalization has reformed the structure, procedure and processes of economic activity of developing and less developed economies. for instance, the introduction of IFRS8 was ultimately pronounced without including country by country reporting ( $\mathrm{CbCR}$ ), requiring only that transnational companies consolidated financial statements are disaggregated to give information about operating segments, which may be identified as either business or geographic segments, depending upon how segments are reported internally. Resulting IFRS8 disclosures conflate individual country activity into broad geographic regions or continents (Crawford, Extance, Helliar, \& Power, 2012). Advocates of this aspect of globalization believe it will be enabled by developing and applying international accounting (and audit) practice that supports the decision-making behavior of [providers of finance]" (Fogarty et al., 1994, p. 41). Which is seen as a means of internal disclosure of the operational activity of individual firms carried out as one of the functions of corporate governance. Notably, IASB pronouncements attract global support from the IMF and the World Bank which have recognized them as benchmarks of good practice for developing and operating capital markets. International regulators such as IOSCO and the Basel Committee, and over 120 countries worldwide, require or permit International Accounting Standard Board's (IASB) pronouncements for corporate reporting (IFRS Foundation, 2013c; IFRS Foundation, 2015a).

Competition for managerial talent between firms has been rising over time. Corporate and public governance, impede corruption and tax evasion as well as accelerate growth, resource mobilization and ultimately social development and poverty reduction in resource-dependent countries (Resource Governance Index, 2010). It is thus expected that companies which adopt recommendations of the Governance Code are likely to enhance their corporate performance (Akbar et al., 2016).

\subsection{Hypothesis Development}

For every country to attract financial inflows there must be good governance, therefore in our research we posit that dimensions of globalization and overall country's governance rating influence corporate governance system. From a practical point of view, the problem of "corporate governance" is concerned with the design of institutions that induce management in their actions, to take into account the welfare of stakeholders-investors, employees, communities, suppliers, and customers. On the other hand, management runs the firm through managing its day to day operations and setting its business strategy. At least, in the "structure-conduct-performance" paradigm, management's perceptions of the market structure and the firm's strengths and weaknesses jointly determine their choice of corporate strategy (long-run plan for profit maximization), and organizational structure (the internal allocation of duties, strategic decision making, and appraisal and reward systems, strategic choice for goal achievement). Strategies adopted or set by various corporate board are influence by the dimensions of globalization (economic, social and political). From KOF globalization measurement point of view, globalization is a multifaceted concept that encompasses much more than openness to trade and capital flows. It also includes citizens of 


\section{Macrothink Institute $^{\mathrm{TM}}$}

different countries communicating with each other and exchanging ideas and information, or governments working together to tackle political problems of global reach (Gygli, Haelg, Potrafke, \& Sturm, 2019). Figure 1 and 2 present the ratings of the dimensions of globalization; Economic globalization (KOFEI), Social globalization (KOFSoGI), Political globalization (KOFPoGI) and the overall globalization rating (KOFGI) on Nigerian and Ghanaian economies. From the ratings, it could be observed that dimensions globalization of Ghana has been increasing from 2012 - 2016 whiles reducing in the Nigerian economy. Especially in the area of economic globalization, Nigeria had a reduction this may be due to long depression period encountered by Nigeria which also led to the reduction in foreign direct investment (FDI) inflows by $11 \%$ in West Africa. Although the overall globalization index shows increasing in the Ghanaian economy, there is a slight reduction in Nigeria.

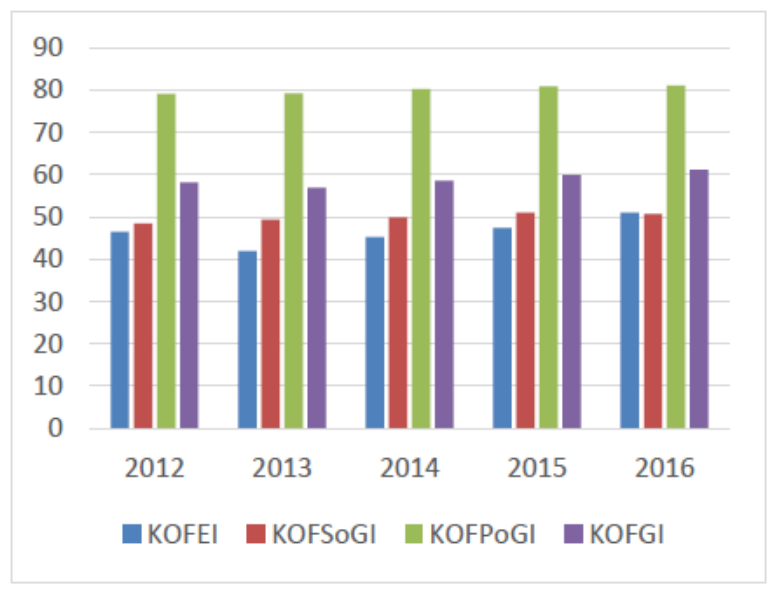

Figure 1. Globalization Index for the period 2012 -2016 (Ghana)

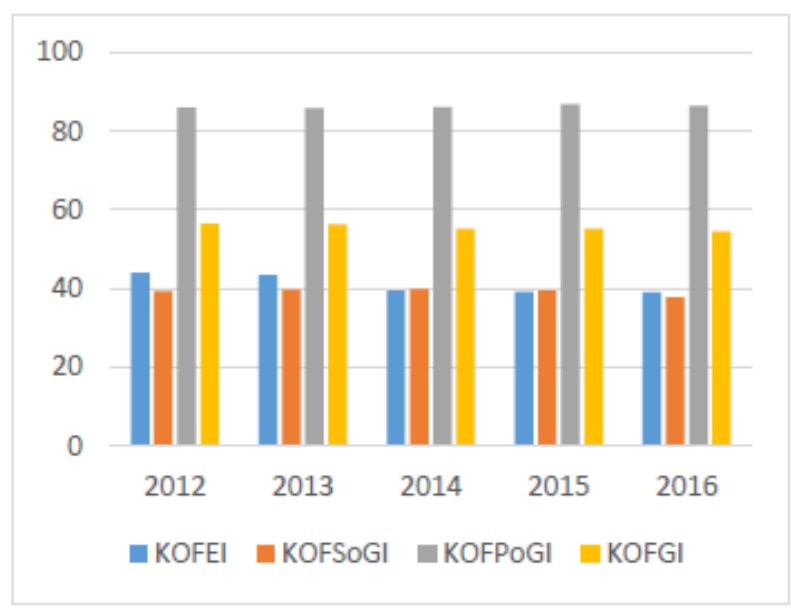

Figure 2. Globalization Index for the period 2012 -2016 (Nigeria)

From KOF globalization index, Failure for corporate leaders to take into consideration drivers of globalization leads to the collapse of corporate enterprises in Africa. This could be traced to IIAG Report (2018) out of 14 sub-categories of governance that compose the IIAG, 
only three have seen large African average decline over the decade: Personal Safety (-6.1), Business Environment (-4.9) and National Security (-4.4). Over the last decade, which has been one of economic growth for the continent, Africa's average progress in Sustainable Economic Opportunity for its citizens has been nearly non-existent. Return on investment on FDI declined in 2012 from $12.3 \%$ to $6.3 \%$ in 2017. The decline is strong in regions that depend on commodity-related FDI. FDI flows to Africa dropped to $\$ 42$ billion in 2017, a $21 \%$ reduction from 2016. FDI remains the biggest external source of finance for Africa and developing economies as a whole. It makes up 39 per cent of total incoming finance in developing economies as a group, but less than a quarter in the less developed economies, with a declining trend since 2012 (World Investment Report, 2018). The decline in FDI and the returns on investment could be attributed to the governance of countries as well as corporations. It is thus expected that companies which adopt recommendations of the Governance Code are likely to enhance their corporate performance (Akbar et al., 2016).

Every country with good governance impacts on corporate governance of firms. The World Bank (1992) discovered governance quality as necessity for development, particularly the type of political regime; in the area of resource development management and exercising of authority; and its capacity to formulate and implement policies. Attention turned to the 'Capable State' and 'Good Governance' to complement market-based policies. Resource-rich countries are seen to have poor democracy/governance, government corruption and may be socially divided by civil wars and human rights abuses (Moffat \& Haralampieva, 2014; Transparency International, 2011; Crawford, 2017). There are high acuities of government corruption in these countries (Transparency International, 2011) with reports of unseen payments made by transnational companies to government officials, or intermediaries, to access the right to explore natural resources (for example, see: Huffington Post \& Fairfax Media, 2016). Good corporate and public governance, impede corruption and tax evasion as well as accelerate growth, resource mobilization and ultimately social development and poverty reduction in resource-dependent countries (Resource Governance Index, 2010). For Africa continent to full benefit of globalization will call for adherence to good corporate and public governance for reduction in corruption and mismanagement of resources. Base on the above we hypothesize the following:

H1 There is a positive relationship between economic globalization and corporate governance index of African firms

$\mathrm{H} 2$ There is a positive relationship between social globalization and corporate governance index of African firms

H3 There is a positive relationship between political globalization and corporate governance index of African firms

\section{Methodology}

This study used a panel data of nonfinancial and insurance companies listed on Nigeria and Ghana stock exchange for the period 2012 - 2016. Data extracted from the annual financial report. Companies with serious missing annual financial data were dropped given a total of 


\section{Ml Macrothink}

Business and Economic Research

ISSN 2162-4860

2020, Vol. 10, No. 1

103 companies from both countries (Nigeria and Ghana) with total observation for the study was 510. In order to access the effect of globalization on firm corporate governance performance of various listed firms in Nigeria and Ghana, the study using KOF Globalization Index which entails composite index measuring globalization for every country in the world along the economic, social and political dimension. It also disentangles trade and financial globalization within the economic dimension of globalization and use time-varying weighting of the variables. We considered KOF Globalization Index as fit in measuring and determine the impact of globalization on corporate governance in developing economies (Ghana \& Nigeria). Table 1 present the sectorial analysis of firms listed in Nigeria and Ghana stock exchange.

Table 1. Sectorial Analysis of Listed firms 2012 -2016

\begin{tabular}{|l|l|}
\hline Industries & Total Number \\
\hline Consumables & 24 \\
\hline Industrial Goods & 17 \\
\hline Oil \& Gas & 13 \\
\hline Natural Resources & 4 \\
\hline Agriculture & 5 \\
\hline Service & 20 \\
\hline Conglomerate & 5 \\
\hline Construction & 4 \\
\hline Health & 7 \\
\hline ICT & 3 \\
\hline
\end{tabular}

\subsection{Dependent Variables}

The dependent variables for the study was corporate governance index developed by Ararat, Black, \& Yurtoglu (2016) in relation to Turkish firms; Munisi \& Randøy (2013) they looked at the corporate governance of firms in Sub-Sahara Africa and OECD (2015) outlined the principals of good corporate governance. This study looks at only board structure, board procedure and board disclosure out of 5 total corporate governance indices (board structure, board procedure, board disclosure, ownership structure and shareholders' right). Additions were made to suit the Ghanaian and Nigerians firms. Element in the sub-indices were coded "1" if applicable to a firm and "0" otherwise; sub-indices and elements are described in Table 2 and brief explanations on them are as follows:

Table 2. Corporate Governance Sub-Indices

\begin{tabular}{|l|l|}
\hline VARIABLE & REFERENCE \\
\hline BOARD STRUCTURE SUBINDEX (BSI) & \\
\hline One independent director on the board & $\begin{array}{l}\text { Munisi \& Randøy (2013); OECD (2015); Ararat, Black, \& } \\
\text { Yurtoglu (2016) }\end{array}$ \\
\hline Chairperson is a non-executive director & Ararat, Black, \& Yurtoglu (2016) \\
\hline $\begin{array}{l}\text { CEO (if on board) and chairman are different } \\
\text { individuals }\end{array}$ & $\begin{array}{l}\text { González, 2008, South Africa IOD, 2009; Munisi \& Randøy } \\
\text { (2013); Ararat, Black, \& Yurtoglu (2016) }\end{array}$ \\
\hline
\end{tabular}




\begin{tabular}{|c|c|}
\hline Is the CEO (General Manager) an outsider & Ararat, Black, \& Yurtoglu (2016) \\
\hline Board has a nominating committee & $\begin{array}{l}\text { Black et al., 2006b, Cadbury, 1992; Munisi \& Randøy } \\
\text { (2013); OECD (2015) }\end{array}$ \\
\hline Audit committee has an independent member & OECD (2015); Ararat, Black, \& Yurtoglu (2016) \\
\hline $\begin{array}{l}\text { Audit committee has non-executive or } \\
\text { independent chair }\end{array}$ & Ararat, Black, \& Yurtoglu (2016); Munisi \& Randøy (2013) \\
\hline Corporate governance committee exists & Ararat, Black, \& Yurtoglu (2016); Munisi \& Randøy (2013) \\
\hline \multicolumn{2}{|l|}{ BOARD PROCEDURE SUBINDEX (BPI) } \\
\hline company has a code of ethics or conduct & OECD (2015); Ararat, Black, \& Yurtoglu (2016) \\
\hline $\begin{array}{l}\text { Corporate governance policy or board charter } \\
\text { governs the board process }\end{array}$ & OECD (2015); Ararat, Black, \& Yurtoglu (2016) \\
\hline Disclosure of members audit committee & $\begin{array}{l}\text { (Munisi \& Randøy, 2013); OECD (2015); Ararat, Black, \& } \\
\text { Yurtoglu (2016) }\end{array}$ \\
\hline Disclosure of audit committee charter & Ararat, Black, \& Yurtoglu (2016) \\
\hline Internal audit function exist & Ararat, Black, \& Yurtoglu (2016) \\
\hline \multicolumn{2}{|l|}{ BOARD DISCLOSURE SUBINDEX (BDI) } \\
\hline $\begin{array}{l}\text { Annual financial statements prepared base on } \\
\text { IFRS and are placed on firm website }\end{array}$ & $\begin{array}{l}\text { Munisi \& Randøy (2013); OECD (2015); Ararat, Black, \& } \\
\text { Yurtoglu (2016) }\end{array}$ \\
\hline $\begin{array}{l}\text { quarterly financial statements are place on } \\
\text { website of the firm }\end{array}$ & Ararat, Black, \& Yurtoglu (2016) \\
\hline Disclosure of material events & OECD (2015); Ararat, Black, \& Yurtoglu (2016) \\
\hline Annual report of firm are paced on firm website & Ararat, Black, \& Yurtoglu (2016) \\
\hline $\begin{array}{l}\text { Firm puts CG compliance report separately on } \\
\text { firm website }\end{array}$ & Ararat, Black, \& Yurtoglu (2016) \\
\hline $\begin{array}{l}\text { Company's annual agenda on corporate events is } \\
\text { put on website }\end{array}$ & Ararat, Black, \& Yurtoglu (2016) \\
\hline $\begin{array}{l}\text { Company's articles of association is placed on } \\
\text { company's website }\end{array}$ & OECD (2015); Ararat, Black, \& Yurtoglu (2016) \\
\hline $\begin{array}{l}\text { Company's includes shareholding voting } \\
\text { information on company's website }\end{array}$ & Ararat, Black, \& Yurtoglu (2016) \\
\hline Reports on CSR activities by the company & Klapper and Love ( 2004); Munisi \& Randøy (2013) \\
\hline Company's discloses on list of insiders & Ararat, Black, \& Yurtoglu (2016) \\
\hline $\begin{array}{l}\text { Company's discloses shareholdings of individual } \\
\text { directors }\end{array}$ & Ararat, Black, \& Yurtoglu (2016) \\
\hline Disclosure of controlling shareholder & Ararat, Black, \& Yurtoglu (2016) \\
\hline Disclosure of corporate governance guidelines & Ararat, Black, \& Yurtoglu (2016) \\
\hline Disclosure code of conduct or ethics code & Ararat, Black, \& Yurtoglu (2016); OECD (2015) \\
\hline Disclosure of last AGM & Ararat, Black, \& Yurtoglu (2016) \\
\hline Disclosure of board members current position & Munisi \& Randøy (2013)Ararat, Black, \& Yurtoglu (2016) \\
\hline $\begin{array}{l}\text { Disclosure of board members educational and } \\
\text { employment history }\end{array}$ & Munisi \& Randøy (2013); Ararat, Black, \& Yurtoglu (2016) \\
\hline $\begin{array}{l}\text { Disclosure on board members date of joining the } \\
\text { board }\end{array}$ & Munisi \& Randøy (2013); Ararat, Black, \& Yurtoglu (2016) \\
\hline senior managers background is disclosed & Munisi \& Randøy (2013); Ararat, Black, \& Yurtoglu (2016) \\
\hline Disclosure on internal audit/control information & Ararat, Black, \& Yurtoglu (2016) \\
\hline Disclosure of number of board meeting & Ararat, Black, \& Yurtoglu (2016) \\
\hline Resolutions made by board are disclosed & Melsa Ararat, Bernard S. Black, B. Burcin Yurtoglu (2016) \\
\hline $\begin{array}{l}\text { Remuneration of executive directors policy is } \\
\text { disclosed }\end{array}$ & $\begin{array}{l}\text { OECD (2015); Munisi \& Randøy (2013); Ararat, Black, \& } \\
\text { Yurtoglu (2016) }\end{array}$ \\
\hline
\end{tabular}

Board Structure: this index entails the made up of the board of directors of various firms. One of the key element looked at was board independence which is seen as key factor in good corporate governance (e.g., Dahya, Dimitrov and McConnell, 2008; Black and Kim, 2012). 


\section{Macrothink}

The number of independent directors on the board is necessary for better decision making. Another element in this sub-index is the CEO duality. CEO duality is seen as CEO of a corporate organization performing a dual role, that is CEO and board chairman. The duality role of CEO causes conflict of interest which hinders the disclosure of some key information for better decision making by the board of directors (Cornett, Marcus, Saunders, \& Tehranian, 2003). Figure 3 present histogram of non-normalized corporate governance sub-index- board structure (BSI) values $(0 \sim 100)$, across sample years (2012-2016). Sample is 510 observations of 102 distinct firms.

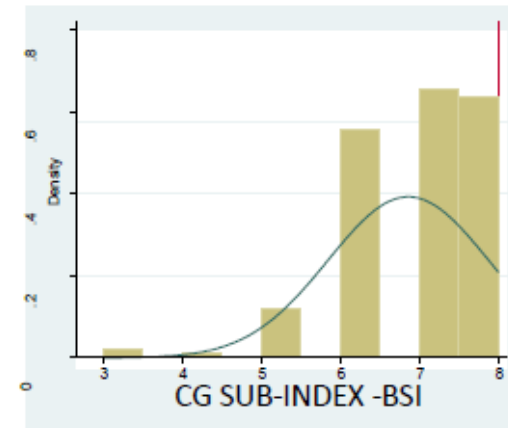

Figure 3. Histogram of non-normalized corporate governance sub-index- Board Structure Index (BSI)

Board Procedure Sub index (5 elements): this index looks at the policies that governs the board proceedings; code of ethics and conduct and corporate governance policy. For every good corporate governance there should be an audit committee. A sub-committee which is independently responsible for the preparation of financial reports and accurate disclosure in compliant with reporting standards with internal control system and strong enough audit standards. Figure 4 present histogram of non-normalized corporate governance sub indexBoard Procedure (BPI) values $(0 \sim 100)$, across sample years (2012-2016). Sample is 510 observations of 102 firms.

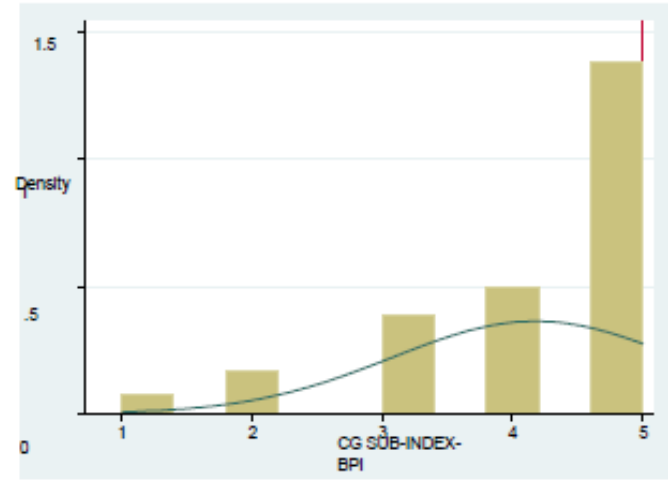

Figure 4. Histogram of non-normalized corporate governance subindex- Board Procedure (BPI) 


\section{MlMacrothink}

Disclosure Sub index (23 elements): elements in this index comprise financial and nonfinancial disclosure. For financial disclosure, key elements in financial reporting as prescribed by International Financial Reporting Standards (IFRS) must be disclosed. Other non-financial disclosure concerning internal control which is material for decision making need to be disclosure by various firms in these two countries (Nigeria and Ghana). Research has shown that corporate governance disclosure predicts a lower cost of equity capital (Farvaque, Refait-Alexandre and Saïdane, 2011; Crawford, 2017). The measurement of these variables is presented Table 2. Figure 5 present the Histogram of non-normalized corporate governance sub index- Board disclosure index (BDI) values $(0 \sim 100)$, across sample years (2012-2016). Sample is 510 observations of 102 distinct firms.

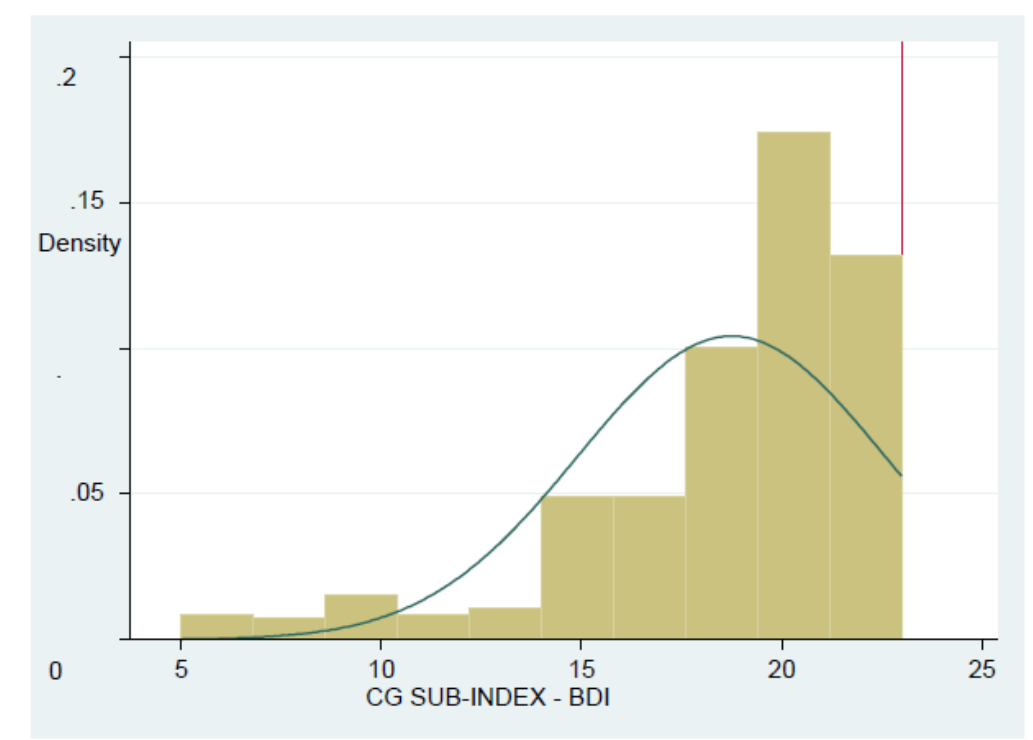

Figure 5. Histogram of non-normalized corporate governance subindex- Board Disclosure Index (BDI)

\subsection{Independent Variables}

The study used KOF Globalization Index which entails composite index measuring globalization for every country in the world along the economic, social and political dimension. It decomposes trade and financial globalization within the economic dimension of globalization and use time-varying weighting of the variables. We also looked at operational performance variables; ROE, working capital, managerial efficiency, the measurement of these variables are presented in Table 3 
Table 3. Variable Definition

\begin{tabular}{|c|c|c|c|}
\hline VARIABLES & $\begin{array}{l}\text { VARIABLE } \\
\text { NAME }\end{array}$ & MEASUREMENT & SOURCE \\
\hline \multicolumn{4}{|l|}{$\begin{array}{l}\text { DEPENDENT } \\
\text { VARIABLES: }\end{array}$} \\
\hline \multicolumn{4}{|l|}{$\begin{array}{l}\text { Corporate } \\
\text { governance index: }\end{array}$} \\
\hline $\begin{array}{l}\text { Board Structure } \\
\text { Subindex }\end{array}$ & BSI & $\begin{array}{l}\text { dummy: ' } 1 \text { ' if it exist and '0' } \\
\text { otherwise }\end{array}$ & Annual financial statement \\
\hline $\begin{array}{l}\text { Board Procedure } \\
\text { Subindex }\end{array}$ & BPI & $\begin{array}{l}\text { dummy: ' } 1 \text { ' if it exist and ' } 0 \text { ' } \\
\text { otherwise }\end{array}$ & Annual financial statement \\
\hline $\begin{array}{l}\text { Board Disclosure } \\
\text { Subindex }\end{array}$ & BDI & $\begin{array}{l}\text { dummy: ' } 1 \text { ' if it exist and ' } 0 \text { ' } \\
\text { otherwise }\end{array}$ & Annual financial statement \\
\hline \multicolumn{4}{|l|}{$\begin{array}{l}\text { INDEPENDENT } \\
\text { VARIABLES: }\end{array}$} \\
\hline $\begin{array}{l}\text { globalisation } \\
\text { index: }\end{array}$ & & $\begin{array}{ll}\text { KOF } & \text { GLOBALISATIONN } \\
\text { INDEX } & \\
\end{array}$ & \\
\hline $\begin{array}{l}\text { economic } \\
\text { globalisation }\end{array}$ & GEI & $\begin{array}{l}\text { KOF globalization } \\
\text { measurement scale }\end{array}$ & 2018 KOF Globalisation index \\
\hline social globalisaion & GSI & $\begin{array}{l}\text { KOF globalization } \\
\text { measurement scale }\end{array}$ & 2018 KOF Globalisation index \\
\hline $\begin{array}{l}\text { political } \\
\text { globalisation }\end{array}$ & GPI & $\begin{array}{l}\text { KOF globalization } \\
\text { measurement scale }\end{array}$ & 2018 KOF Globalisation index \\
\hline \multicolumn{4}{|l|}{$\begin{array}{l}\text { OPERATIONAL } \\
\text { PERFORMANCE: }\end{array}$} \\
\hline Return on equity & ROE & $\begin{array}{l}\text { net profit before interest and } \\
\text { tax divided by total equity }\end{array}$ & \\
\hline $\begin{array}{l}\text { Managerial } \\
\text { efficiency }\end{array}$ & MAEFF & $\begin{array}{l}\text { Total revenue divided by total } \\
\text { assets }\end{array}$ & $\begin{array}{l}\text { Seema Miglani, Kamran Ahmed, } \\
\text { Darren Henry (2014) }\end{array}$ \\
\hline $\begin{array}{l}\text { working capital } \\
\text { management }\end{array}$ & WCM & $\begin{array}{l}\text { total current assets - total } \\
\text { current liabilities }\end{array}$ & \\
\hline \multicolumn{4}{|l|}{$\begin{array}{l}\text { CONTROL } \\
\text { VARIABLES: }\end{array}$} \\
\hline Growth & GROTH & Natural logarithm of total sales & \\
\hline $\begin{array}{l}\text { international } \\
\text { auditing firm }\end{array}$ & Big 4 & $\begin{array}{l}\text { Dummy: ' } 1 \text { ' if the firm use the } \\
\text { services of one of the big } 4 \\
\text { auditing firms }\end{array}$ & $\begin{array}{l}\text { Gady Jacoby, Yingqi Li, Tianze Li, } \\
\text { Steven Xiaofan Zheng (2017) }\end{array}$ \\
\hline firms age & FAGE & $\begin{array}{l}\text { Natural logarithm of existing } \\
\text { firm's age }\end{array}$ & $\begin{array}{l}\text { Nadarajah Sivathaasan, Searat Ali, } \\
\text { Benjamin Liu, Allen Haung (2016) }\end{array}$ \\
\hline $\begin{array}{l}\text { country' overall } \\
\text { governance rating }\end{array}$ & GOVR & 2018 IIAG RATING & $\begin{array}{l}\begin{array}{l}2018 \text { Ibrahim Index } \\
\text { Governance }\end{array} \\
\text { Of African }\end{array}$ \\
\hline
\end{tabular}

\subsection{Control Variables}

The control variables for the study were growth, firm's age, country's governance performance by using governance index of IIAG (2018). Audit reputation (BIG 4 auditing firms) (Big 4- EY, Deloitte, KPMG and PricewaterhouseCoopers), the measurement of these variables are presented in Table 3

\subsection{Empirical Models}

In line with the study of Carsun and Sun (2007), Asongu and Le Roux (2017) and Kazeem B. 
Ajide, Ibrahim D. Raheem, Simplice A. Asongu (2019) our study used the Tobit model which entails the simultaneous use of maximum likelihood estimation and probit model. This study use Tobit model due to the censored nature of the data. Base on this, both Ordinary Least Square (OLS) and Tobit model were used for the study.

The standard Tobit model (Tobin, 1958; Carsun \& Sun, 2007) is as follows in Eq. 1

$$
y_{i, t}^{*}=\alpha_{0}+\beta \mathrm{X}_{i, t}+\varepsilon_{i, t},
$$

Where $y_{i, t}^{*}$ represent the latent response variable, $\alpha_{0}$ is the constant, $\mathrm{X}_{i, t}$ is an observed $(1 \mathrm{x}$ $k$ ) vector of explanatory variables, $\varepsilon_{i, t} \approx$ i.i.d. $\mathrm{N}\left(0, \sigma^{2}\right)$ and is independent variables of $\mathrm{X}_{i, t}$. Instead of observing $y_{i, t}^{*}$, we observed $y_{i, t}$ in Eq. (2)

$$
y_{i, t}=\left\{\begin{array}{l}
y_{i, t}^{*}, i f y_{i, t}^{*}>\gamma \\
0, i f y_{i, t}^{*} \leq \gamma
\end{array}\right.
$$

Where $\gamma$ is a non-stochastic constant. In other words, the value of $y_{i, t}^{*}$ is missing when it is less than or equal to $\gamma$.

Ordinary Least Square Model

$$
\begin{gathered}
B S I=\beta_{1}+\beta_{2} * G E I+\beta_{3}^{*} G S I+\beta_{4}^{*} G P I+\beta_{5} * R O E+\beta_{6} * M A E F F+\beta_{7} * W C E+\beta_{8}^{*} G R O W T H+\beta_{9}^{*} B I G 4+\beta_{10} * F A G E+\beta_{11} * G O V+\varepsilon \\
B P I=\beta_{1}+\beta_{2} * G E I+\beta_{3} * G S I+\beta_{4} * G P I+\beta_{5} * R O E+\beta_{6} * M A E F F+\beta_{7} * W C E+\beta_{8} * G R O W T H+\beta_{9} * B I G 4+\beta_{10} * F A G E+\beta_{11} * G O V+\varepsilon \\
B D I=\beta_{1}+\beta_{2} * G E I+\beta_{3}^{*} G S I+\beta_{4} * G P I+\beta_{5} * R O E+\beta_{6} * M A E F F+\beta_{7} * W C E+\beta_{8}^{*} G R O W T H+\beta_{9}^{*} B I G 4+\beta_{10} * F A G E+\beta_{11} * G O V+\varepsilon
\end{gathered}
$$

\section{GMM Model}

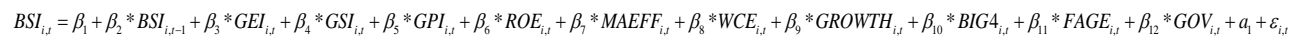

$$
\begin{aligned}
& B P I_{i, t}=\beta_{1}+\beta_{2} * B I_{i, t-1}+\beta_{3} * G E I_{i, t}+\beta_{4} * G S I_{i, t}+\beta_{5} * G P I_{i, t}+\beta_{6} * R O E_{i, t}+\beta_{7} * M A E F F_{i, t}+\beta_{8} * W C E_{i, t}+\beta_{9} * G R O W T H_{i, t}+\beta_{10} * B I G 4_{i, t}+\beta_{11} * F A G E_{i, t}+\beta_{12} * G O V_{i, t}+a_{1}+\varepsilon_{i, t}
\end{aligned}
$$

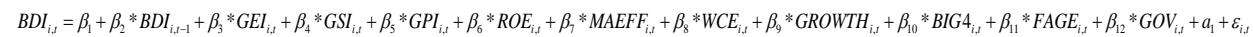

Endogeneity could affect the estimated result, therefore to control it the study used ArellanoBond's (1991) two-step Generalized Method of Moments (GMM) using Eq. (6-8) and Tobit Instrumental variable regression. The endogeneity issue occurs when an independent variable is correlated with errors $\varepsilon i, t$, which is often caused by omitted variables, measurement errors, or simultaneity between dependent variables and independent variables. The most efficient way to deal with endogeneity is developing proper instrumental variables, which have strong 
correlation with endogenous independent variables but are not correlated with errors. A lagged regressor can be used as an instrument and the lagged differences of all the independent variables can also be used as instruments to avoid exogenous issues (Arellano and Bond, 1991).

\section{Analysis}

Table 4 presents the descriptive statistics of all variables used in our analyses. For our dependent variables board structure index (BSI), board procedure index (BPI) and board disclosure index (BDI) ranges from 1 to 8 with mean value of $6.86,1$ to 5 with mean value 4.17 and 5 to 23 with mean value of 18.75 respectively. For globalization variables, we looked at all the three main dimensions; economic, social and political ranging from 39.066 to 51.00 with mean of $42.00,37.67$ to 51.00 with a mean of 41.16 and $79.02-86.87$ with a mean value of 85.08 respectively. This shows how the developing countries are embracing globalization in the past years. The ROE ranges from -1.77 to 2.65 with average mean value of 0.013 implying that the return on investment is very low this confirms the study of IIAG 2018 that there is a drop on returns on investment on in most of the developing countries leading to drop in inflow FDI. Working capital management and managerial efficiency are having mean value of 3851162 and 1.03 respectively showing the utilization of investment in assets. The maximum (minimum) value of Growth ranges from 3.25 to 9.18 with mean value of 6.66, audit reputation (Big 4) ranges from 0 to 1 with mean of 0.55 implies that more than $50 \%$ of the firms listed in Nigeria and Ghana utilizes the service of the big 4 audit firms in the world, adding to the extent of these firms reporting in accordance with IFRS contributing to globalization. firm's age ranges from 0 to 1.70 with mean value of 1.2 . Maximum (minimum) of GOVR ranges from 0.44 to 0.67 with mean of 0.495 implying that governance rating of Nigeria and Ghana from 2012 to 2016 falls below 50\% which have a significant impact on corporate governance of organizations.

Table 4. Descriptive Statistics

\begin{tabular}{|l|l|l|l|l|l|}
\hline Variable & Obs & Mean & Std. Dev. & Min & Max \\
\hline BSI & 510 & 6.864706 & 1.01817 & 3 & 8 \\
\hline BPI & 510 & 4.17451 & 1.099624 & 1 & 5 \\
\hline BDI & 510 & 18.74902 & 3.825741 & 5 & 23 \\
\hline GEI & 510 & 42.00108 & 3.139792 & 39.06671 & 51.00101 \\
\hline GSI & 510 & 41.16816 & 4.230098 & 37.68982 & 51.01119 \\
\hline GPI & 510 & 85.08677 & 2.471059 & 79.02924 & 86.87934 \\
\hline ROE & 510 & 0.013773 & 7.537667 & -1.7782 & 1.6522 \\
\hline MAEFF & 510 & 1.009252 & 0.928021 & 0 & 10.40887 \\
\hline WCM & 510 & -3851163 & 29600000 & -322000000 & 64000000 \\
\hline GROWTH & 510 & 6.67456 & 1.129638 & 3.256426 & 9.184097 \\
\hline BIG4 & 510 & 0.558824 & 0.497015 & 0 & 1 \\
\hline FAGE & 510 & 23.30784 & 12.57251 & 1 & 51 \\
\hline IIAG & 510 & 0.495618 & 0.078823 & 0.444 & 0.672 \\
\hline
\end{tabular}

Table 5 present correlations among variables. The three dimensions' globalization variables correlated significantly with corporate governance sub-indices (BSI, BPI \& BDI). Also operational performance variables (ROE, WCM, Managerial efficiency) and country's 
governance rating correlated with corporate governance sub-indices. There are no serious multicollinearity problems among the dependent variables but some the coefficient of independent variables was greater than 0.7 . In other to deal with multicollinearity GMM was conducted, this is presented in Table 6 model 4 - 6 .

Table 5. Pearson Correlation

\begin{tabular}{|l|l|l|l|l|l|l|l|l|l|l|l|l|l|}
\hline & BSI & BPI & BDI & GEI & GSI & GPI & ROE & MAEFF & WCM & GROWTH & BIG4 & FAGE & IIAG \\
\hline BSI & & & & & & & & & & & & & \\
\hline BPI & 0.2879 & 1 & & & & & & & & & & & \\
\hline BDI & 0.3897 & 0.4447 & 1 & & & & & & & & & & \\
\hline GEI & -0.0293 & -0.1169 & -0.1674 & 1 & & & & & & & & & \\
\hline GSI & 0.1236 & -0.0492 & -0.0829 & 0.7114 & 1 & & & & & & & & \\
\hline GPI & -0.0813 & 0.0718 & 0.1025 & -0.6723 & -0.9559 & 1 & & & & & & & \\
\hline ROE & -0.0621 & 0.054 & -0.0246 & 0.0124 & 0.009 & -0.01 & 1 & & & & & & \\
\hline MAEFF & 0.1039 & 0.0711 & 0.0541 & 0.0758 & 0.1039 & -0.105 & 0.0323 & 1 & & & & & \\
\hline WCM & 0.0714 & -0.0225 & -0.07 & 0.0865 & 0.0649 & -0.065 & 0.0122 & 0.0655 & 1 & & & & \\
\hline GROWTH & 0.1487 & 0.1954 & 0.298 & -0.4461 & -0.6414 & 0.6491 & -0.009 & -0.0857 & -0.255 & 1 & & & \\
\hline BIG4 & 0.2468 & 0.2777 & 0.2258 & 0.0808 & 0.1186 & -0.119 & 0.056 & 0.1003 & -0.097 & 0.1468 & 1 & & \\
\hline FAGE & 0.1523 & 0.1914 & 0.1624 & -0.2398 & -0.2949 & 0.305 & 0.0917 & 0.12 & 0.0155 & 0.2212 & 0.064 & 1 & \\
\hline IIAG & 0.1504 & -0.0209 & -0.0438 & 0.6165 & 0.9446 & -0.963 & 0.0102 & 0.0954 & 0.0592 & -0.645 & 0.119 & -0.281 & 1 \\
\hline
\end{tabular}

Table 6. OLS regression of dimensions of globalization on corporate governance sub indices

\begin{tabular}{|c|c|c|c|c|c|c|}
\hline & 1 & 2 & 3 & 4 & 5 & 6 \\
\hline VARIABLES & BSI & BPI & BDI & BSI & BPI & BDI \\
\hline \multirow[t]{2}{*}{ GEI } & $-0.0547 * * *$ & $-0.0386^{*}$ & $-0.187 * *$ & $-0.0547 * * *$ & $-0.0386^{*}$ & $-0.187 * *$ \\
\hline & -0.0185 & -0.0213 & -0.0723 & -0.0178 & -0.0225 & -0.0753 \\
\hline \multirow[t]{2}{*}{ GSI } & $0.124 * * *$ & 0.0496 & 0.166 & $0.124 * * *$ & 0.0496 & 0.166 \\
\hline & -0.0359 & -0.0413 & -0.14 & -0.033 & -0.0419 & -0.136 \\
\hline \multirow[t]{2}{*}{ GPI } & $0.341 * * *$ & $0.262 * * *$ & $0.925^{* * *}$ & 0.341 *** & $0.262^{* * * *}$ & $0.925^{* * *}$ \\
\hline & -0.07 & -0.0805 & -0.274 & -0.0574 & -0.0865 & -0.281 \\
\hline \multirow[t]{2}{*}{ ROE } & $-0.0117 * *$ & 0.0042 & -0.0208 & $-0.0117 * * *$ & 0.0042 & $-0.0208 * * *$ \\
\hline & -0.00521 & -0.006 & -0.0204 & -0.0027 & -0.00559 & -0.00628 \\
\hline \multirow[t]{2}{*}{ MAEFF } & $0.0715^{*}$ & 0.0502 & 0.199 & $0.0715^{* *}$ & 0.0502 & 0.199 \\
\hline & -0.0431 & -0.0497 & -0.169 & -0.0326 & -0.0506 & -0.13 \\
\hline \multirow[t]{2}{*}{ WCM } & $0.00572 * * *$ & 0.000181 & 0.000462 & $0.000572^{* * * *}$ & 0.000181 & 0.000462 \\
\hline & -0.0000139 & -0.0001 .60 & -0.0005 .42 & -0.0001 .33 & -0.0001 .27 & -0.0003 .80 \\
\hline \multirow[t]{2}{*}{ GROWTH } & $0.354 * * *$ & $0.203 * * *$ & $1.300 * * *$ & $0.354 * * *$ & $0.203 * * *$ & $1.300 * * *$ \\
\hline & -0.0498 & -0.0574 & -0.195 & -0.0453 & -0.0624 & -0.172 \\
\hline \multirow[t]{2}{*}{ BIG4 } & $0.300 * * *$ & $0.499 * * *$ & $1.088^{* * * *}$ & $0.300 * * *$ & $0.499 * * *$ & $1.088 * * * *$ \\
\hline & -0.0839 & -0.0965 & -0.328 & -0.0812 & -0.0946 & -0.351 \\
\hline \multirow[t]{2}{*}{ FAGE } & $0.0117 * * *$ & $0.0117 * * *$ & $0.0302 * *$ & $0.0117 * * *$ & $0.0117 * * *$ & $0.0302 * *$ \\
\hline & -0.00334 & -0.00385 & -0.0131 & -0.00325 & -0.00338 & -0.013 \\
\hline \multirow[t]{2}{*}{ IIAG } & $10.66 * * *$ & $7.965^{* * *}$ & $34.22 * * *$ & $10.66 * * *$ & $7.965 * * *$ & $34.22 * * *$ \\
\hline & -2.011 & -2.315 & -7.868 & -2.006 & -2.16 & -7.33 \\
\hline \multirow[t]{2}{*}{ Constant } & $-33.10 * * *$ & $-24.43 * * *$ & $-86.07 * * *$ & $-33.10 * * *$ & $-24.43 * * *$ & $-86.07 * * *$ \\
\hline & -7.304 & -8.409 & -28.58 & -5.93 & -9.2 & -29.47 \\
\hline R-squared & 0.266 & 0.166 & 0.204 & 0.266 & 0.166 & 0.204 \\
\hline Observations & 510 & 510 & 510 & 510 & 510 & 510 \\
\hline
\end{tabular}

Notes: Standard errors in parentheses. ${ }^{*} \mathrm{p}<0.1,{ }^{* *} \mathrm{p}<0.05,{ }^{* * *} \mathrm{p}<0.01$. 


\section{Macrothink}

Business and Economic Research ISSN 2162-4860 2020, Vol. 10, No. 1

From OLS regression analysis presented in Table 6 model 1-3, all the globalization dimensions (economic, social and political) are all significant correlated with BSI, BPI and BDI. This shows that globalization has influence the governance of the developing economies. good governance and corporate governance policy attract foreign investors and encourage firm expansion into other geographical areas. Operational performance variables ROE, MEFF, WCM were significant in BSI but not BPI and BDI the may be plausibly attributed to the governance policy and code of ethics which are put in place to guide operational activities. Growth and firm's age were significant in all the models. As firm expands new and innovative ways of carrying out business activities is adopted by having a modeled organization which is normally an international organization in the case of firms in developing economies, to improve their activities to meet international standards. Therefore, as firm grows and age better corporate governance mechanisms are adopted to enhance efficient and effective business operation to satisfy the needs of stakeholders.

Table 7. Tobit Regression of dimensions of globalization on corporate governance sub-indices

\begin{tabular}{|l|l|l|l|}
\hline & 1 & 2 & 3 \\
\hline VARIABLES & BSI & BPI & BDI \\
\hline GEI & $-0.0596^{* * *}$ & $-0.0530^{*}$ & $-0.200^{* * *}$ \\
\hline & -0.0217 & -0.0301 & -0.0386 \\
\hline GSI & $0.194^{* * *}$ & $0.107^{*}$ & $0.149 *$ \\
\hline & -0.0438 & -0.0635 & -0.0834 \\
\hline GPI & $0.572^{* * *}$ & $0.640^{* * *}$ & $1.200^{* * *}$ \\
\hline & -0.0872 & -0.127 & -0.166 \\
\hline ROE & $-0.0149^{*}$ & 0.000665 & -0.0109 \\
\hline & -0.00863 & -0.00742 & -0.0116 \\
\hline MAEFF & 0.106 & -0.1 & -0.133 \\
\hline & -0.0849 & -0.11 & -0.171 \\
\hline WCM & $0.000450^{* *}$ & 0.000640 & -0.000103 \\
\hline & -0.0002 .28 & -0.000359 & -0.000503 \\
\hline GROWTH & $0.469^{* * *}$ & $0.387 *$ & $0.752^{*}$ \\
\hline & -0.106 & -0.219 & -0.396 \\
\hline BIG4 & $0.358^{* *}$ & $1.206^{* * *}$ & $1.409^{*}$ \\
\hline & -0.181 & -0.396 & -0.757 \\
\hline FAGE & $0.0206^{* * *}$ & $0.0406^{* *}$ & $0.0599^{* *}$ \\
\hline & -0.00724 & -0.0158 & -0.0298 \\
\hline IIAG & $16.42^{* * *}$ & $19.24 * * *$ & $39.59^{* * *}$ \\
\hline & -2.485 & -3.69 & -4.951 \\
\hline Constant & $-59.00^{* * *}$ & $-65.15^{* * * *}$ & $-107.5^{* * *}$ \\
\hline & -9.098 & -12.98 & -15.92 \\
\hline sigma_u & $0.717^{* * *}$ & $1.677^{* * *}$ & $3.501^{* * *}$ \\
\hline & -0.076 & -0.177 & -0.277 \\
\hline sigma_e & $0.952^{* * *}$ & $1.121 * * *$ & $1.755^{* * *}$ \\
\hline & -0.0432 & -0.066 & -0.0687 \\
\hline Observations & 510 & 510 & 510 \\
\hline & & & \\
\hline
\end{tabular}

Notes: Standard errors in parentheses. ${ }^{*} \mathrm{p}<0.1, * * \mathrm{p}<0.05, * * * \mathrm{p}<0.01$.

The impact of globalization on corporate governance mechanisms is presented in Table 7 
using Tobit model. From the analysis, all the dimensions of globalization significantly influence all the estimated models (BSI, BPI, BDI). Economic globalization (GEI) had a negative significant influence BSI \& BDI at $1 \%$ but $10 \%$ in BPI. Social globalization (GSI) positively influence BSI at $1 \%$ but $10 \%$ in both BPI \& BDI. Political globalization positively strongly influences all the corporate governance sub-indices (BSI, BPI, BDI). This shows how globalization influences the governing structure institution. Developing economies experience greater impact of globalization to enable them put better administrative structures in place for the utilization of scarce resource. The continued advocacy of the World Bank (WB) and the International Monetary Fund (IMF) for New Public Management (NPM) in government departments seeks a shift from input and process accountability (bureaucracy, rules, regulations) to results (appraising civil servants against key performance indicators); granting local managers greater discretion over means (subject to budget constraints); tendering out services; reconstructing civil service organizations around programs; and improved reporting, accountability and monitoring mechanisms (Awio, Lawrence, \& Northcott, 2007).

In order to deal with endogeneity issue and to ensure consistence in for previous presented results, instrumental variable Tobit regression was used. This is presented in Table 8. There was a sharp difference in the result presented in the previous Table (Table 7) among these was the influence of the economic globalization (GEI) on BSI, BPI \& BDI; significant in BSI and BDI at $10 \%$. Social globalization (GSI) was significant on only BSI at $5 \%$ but not significant in BPI and BDI. Political globalization (GPI) remains significant in all the estimated models. The overall governance rating (GOVR) of the country was significant at $1 \%$ in all the estimated models. Operational performance was less significant in BSI, BPI \& BDI.

Table 8. Robustness Test with IVTOBIT Result

\begin{tabular}{|l|l|l|l|}
\hline & 1 & 2 & 3 \\
\hline VARIABLES & BSI & BPI & BDI \\
\hline GEI & $-0.0615^{*}$ & -0.0624 & $-0.211^{*}$ \\
\hline & -0.0335 & -0.0855 & -0.108 \\
\hline GSI & $0.154^{* *}$ & -0.0595 & -0.0151 \\
\hline & -0.0698 & -0.178 & -0.223 \\
\hline GPI & $0.714^{* * *}$ & $1.126^{* * *}$ & $1.721^{* * *}$ \\
\hline & -0.143 & -0.365 & -0.455 \\
\hline ROE & $-0.0205^{*}$ & 0.0132 & -0.00858 \\
\hline & -0.0119 & -0.0233 & -0.0303 \\
\hline MAEFF & 0.0414 & -0.302 & -0.0995 \\
\hline & -0.0951 & -0.232 & -0.294 \\
\hline WCM & 0.0258 & $-0.0162^{*}$ & -0.0165 \\
\hline & -0.0348 & -0.0915 & -0.0115 \\
\hline GROWTH & -0.0285 & $-1.541^{* *}$ & -0.599 \\
\hline & -0.298 & -0.765 & -0.962 \\
\hline FAGE & -0.00674 & -0.0535 & -0.0611 \\
\hline & -0.0131 & -0.0336 & -0.0425 \\
\hline IIAG & $15.07 * * *$ & 13.85 & $38.88^{* * *}$ \\
\hline & -3.878 & -9.894 & -12.42 \\
\hline Constant & $-65.12^{* * *}$ & $-82.96^{* *}$ & $-134.0^{* * *}$ \\
\hline & -13.73 & -34.65 & -43.25 \\
\hline
\end{tabular}




\begin{tabular}{|l|l|l|l|}
\hline Alpha & $-2.758 * *$ & $-9.696 * * *$ & $-9.484 * *$ \\
\hline & -1.321 & -3.401 & -4.288 \\
\hline $\operatorname{lns}$ & $0.183 * * *$ & $0.692 * * *$ & $1.359 * * *$ \\
\hline & -0.0414 & -0.0558 & -0.0353 \\
\hline $\operatorname{lnv}$ & $-1.057 * * *$ & $-1.057 * * *$ & $-1.057 * * *$ \\
\hline & -0.0313 & -0.0313 & -0.0313 \\
\hline WALD & 112 & 32.05 & 76.43 \\
\hline CHI2 (PROB) & 0.0368 & 0.0044 & 0.027 \\
\hline Observations & 510 & 510 & 510 \\
\hline
\end{tabular}

Notes: Standard errors in parentheses. ${ }^{*} \mathrm{p}<0.1, * * \mathrm{p}<0.05, * * * \mathrm{p}<0.01$.

Table 9. Sectorial Analysis of Impact of Globalization On Corporate Governance Sub-Indices

\begin{tabular}{|c|c|c|c|c|c|c|c|c|c|}
\hline & IND & IND & IND & CONS & CONS & CONS & OIL \&GAS & OIL \&GAS & OIL \&GAS \\
\hline VARIABLES & BSI & BPI & BDI & BSI & BPI & BDI & BSI & BPI & BDI \\
\hline \multirow[t]{2}{*}{ GEI } & -0.0556 & 0.0365 & $-0.186^{*}$ & -0.0432 & -0.0676 & $-0.165^{* *}$ & -0.0426 & -0.145 & $-0.176^{* *}$ \\
\hline & -0.0608 & -0.097 & -0.106 & -0.032 & -0.0617 & -0.0689 & -0.0747 & -0.0904 & -0.0844 \\
\hline \multirow[t]{2}{*}{ GSI } & $0.372 * * *$ & -0.125 & 0.171 & 0.0819 & $0.263^{* * *}$ & -0.056 & 0.236 & $0.553 * *$ & $0.307 *$ \\
\hline & -0.122 & -0.198 & -0.232 & -0.0668 & -0.13 & -0.149 & -0.155 & -0.216 & -0.169 \\
\hline \multirow[t]{2}{*}{ GPI } & $0.554 * *$ & 0.3 & $1.520 * * *$ & $0.323^{* * *}$ & $0.988^{* * * *}$ & $1.016^{* * * *}$ & $0.905^{* * * *}$ & 0.702 & $0.671^{*}$ \\
\hline & -0.238 & -0.381 & -0.458 & -0.136 & -0.286 & -0.307 & -0.346 & -0.477 & -0.348 \\
\hline \multirow[t]{2}{*}{ ROE } & -0.0152 & -0.446 & -0.247 & 0.0412 & -0.0562 & 0.0216 & -0.359 & 0.202 & -0.523 \\
\hline & -0.202 & -0.382 & -0.371 & -0.046 & -0.0697 & -0.0984 & -0.32 & -0.377 & -0.399 \\
\hline \multirow[t]{2}{*}{ MAEFF } & 0.253 & -1.078 & 1.466 & -0.243 & 0.214 & -0.0905 & 0.166 & $-0.245 * *$ & $-0.262 *$ \\
\hline & -0.453 & -0.947 & -1.282 & -0.18 & -0.346 & -0.421 & -0.117 & -0.113 & -0.148 \\
\hline \multirow[t]{2}{*}{ WCM } & 0.209 & 0.0622 & 0.0678 & -0.0126 & -0.011 & -0.0277 & $0.0123^{* * *}$ & -0.0186 & 0.0376 \\
\hline & -0.0613 & -0.0841 & -0.0112 & -0.0307 & -0.0513 & -0.0698 & -0.0355 & -0.033 & -0.0793 \\
\hline \multirow[t]{2}{*}{ GROWTH } & 0.396 & $-1.158^{* *}$ & 0.249 & 0.175 & $1.460^{* * * *}$ & $1.937 * * *$ & $0.466^{*}$ & 0.99 & 0.722 \\
\hline & -0.282 & -0.588 & -1.087 & -0.312 & -0.54 & -0.723 & -0.249 & -0.62 & -0.688 \\
\hline \multirow[t]{2}{*}{ BIG4 } & 0.533 & $2.176^{* *}$ & 0.712 & 1.04 & -0.221 & -0.142 & 0.54 & 0.369 & $3.920 * * *$ \\
\hline & -0.429 & -0.941 & -1.927 & -0.646 & -1.225 & -1.668 & -0.48 & -1.04 & -1.462 \\
\hline \multirow[t]{2}{*}{ FAGE } & $0.0373^{* * *}$ & 0.0455 & 0.108 & 0.0257 & 0.0341 & -0.00965 & 0.0233 & 0.0993* & $0.195 * * *$ \\
\hline & -0.0176 & -0.0381 & -0.0742 & -0.0205 & -0.0402 & -0.0548 & -0.0178 & -0.0527 & -0.056 \\
\hline \multirow[t]{2}{*}{ IIAG } & 7.085 & -2.922 & $41.59 * * *$ & $10.26^{* *}$ & $33.30 * * *$ & $51.74 * * *$ & $24.45^{* * * *}$ & 16.35 & $31.61 * * *$ \\
\hline & -7.063 & -11.78 & -14.09 & -4.173 & -8.898 & -9.229 & -9.16 & -10.33 & -10.01 \\
\hline \multirow[t]{2}{*}{ Constant } & $-60.36 * *$ & -8.918 & $-136.6^{* * *}$ & $-29.49 * *$ & $-114.2 * * *$ & $-96.45^{* * *}$ & $-93.61 * *$ & $-88.18 *$ & $-69.02 * *$ \\
\hline & -25.49 & -39.8 & -45.38 & -12.38 & -27.18 & -27.37 & -36.72 & -51.1 & -33.09 \\
\hline \multirow[t]{2}{*}{ sigma_u } & $0.620 * * *$ & 1.350 *** & $3.485 * * *$ & $0.891 * * *$ & $1.690 * * *$ & $2.462 * * *$ & 0.0534 & $1.034 * * *$ & $1.618 * * *$ \\
\hline & -0.179 & -0.427 & -0.741 & -0.188 & -0.383 & -0.402 & -1.199 & -0.374 & -0.406 \\
\hline \multirow[t]{2}{*}{ sigma_e } & $1.071^{* * * *}$ & $1.388^{* * * *}$ & $1.876^{* * * *}$ & $0.705^{* * *}$ & $1.109 * * *$ & $1.617 * * *$ & $1.011^{* * * *}$ & $0.880 * * *$ & $1.307 * * *$ \\
\hline & -0.118 & -0.237 & -0.189 & -0.0663 & -0.142 & -0.127 & -0.16 & -0.168 & -0.163 \\
\hline Observations & 85 & 85 & 85 & 120 & 120 & 120 & 65 & 65 & 65 \\
\hline
\end{tabular}

Notes: Standard errors in parentheses. ${ }^{*} \mathrm{p}<0.1,{ }^{*} \mathrm{p}<<0.05, * * * \mathrm{p}<0.01$

Continuation

\begin{tabular}{|l|l|l|l|l|l|l|}
\hline & NAT. RES & NAT. RES & NAT. RES & AGRIC & AGRIC & AGRIC \\
\hline VARIABLES & BSI & BPI & BDI & BSI & BPI & BDI \\
\hline & & & & & & \\
\hline GEI & $-0.130^{* *}$ & $-0.0847 * *$ & $-0.421 * * *$ & -0.0119 & -0.128 & 0.0165 \\
\hline & -0.0584 & -0.0384 & -0.0865 & -0.0625 & -0.155 & -0.135 \\
\hline
\end{tabular}




\begin{tabular}{|c|c|c|c|c|c|c|}
\hline \multirow[t]{2}{*}{ GSI } & $-0.942 * *$ & 0.346 & 0.0152 & $0.332 * * *$ & $-0.825 * * *$ & 0.29 \\
\hline & -0.441 & -0.218 & -0.541 & -0.129 & -0.306 & -0.282 \\
\hline \multirow[t]{2}{*}{ GPI } & $1.553 * * *$ & 0.102 & $2.511 * * *$ & $1.004 * * *$ & -0.603 & $2.201 * * *$ \\
\hline & -0.482 & -0.242 & -0.56 & -0.246 & -0.621 & -0.573 \\
\hline \multirow[t]{2}{*}{ ROE } & 0.16 & $0.308 * * *$ & $0.488 * *$ & 0.51 & $-5.569 *$ & 0.899 \\
\hline & -0.112 & -0.0688 & -0.193 & -1.112 & -3.167 & -2.302 \\
\hline \multirow[t]{2}{*}{ MAEFF } & 0.269 & 1.006 & 0.0602 & -1.299 & 0.705 & -0.209 \\
\hline & -1.639 & -0.845 & -1.764 & -1.088 & -1.265 & -1.357 \\
\hline \multirow[t]{2}{*}{ WCM } & $-0.0988 * * *$ & $-0.0750 * * *$ & $0.0173 * * *$ & -0.0249 & $0.0319 * *$ & $-0.0265^{*}$ \\
\hline & -0.0367 & -0.0247 & -0.0530 & -0.0742 & -0.0157 & -0.0153 \\
\hline \multirow[t]{2}{*}{ GROWTH } & 0.34 & $0.863 * *$ & -0.111 & 0.584 & -1.095 & $7.348 * * *$ \\
\hline & -0.664 & -0.358 & -0.76 & -0.717 & -1.379 & -1.534 \\
\hline \multirow[t]{2}{*}{ BIG4 } & $41.31 * * *$ & -6.044 & 12.21 & 0.178 & -0.934 & $-9.462 * * *$ \\
\hline & -13.85 & -5.353 & -13.09 & -1.004 & -1.201 & -1.636 \\
\hline \multirow[t]{2}{*}{ FAGE } & $0.0441 *$ & $0.0447 * * *$ & $-0.0735^{* *}$ & 0.0866 & -0.116 & $-0.384 * * *$ \\
\hline & -0.0264 & -0.0165 & -0.0354 & -0.0874 & -0.104 & -0.115 \\
\hline \multirow[t]{2}{*}{ IIAG } & $-84.72 * *$ & $26.70 * *$ & 47.94* & $27.61 * * *$ & $-25.90 *$ & $37.07 * * *$ \\
\hline & -34.36 & -11.09 & -25.92 & -7.052 & -15.52 & -13.67 \\
\hline \multirow[t]{2}{*}{ Constant } & $-50.62 * *$ & $-34.46 * *$ & $-203.0 * * *$ & $-110.0 * * *$ & $116.7 *$ & $-241.3 * * *$ \\
\hline & -23.64 & -15 & -31.19 & -22.95 & -67.6 & -53.72 \\
\hline \multirow[t]{2}{*}{ sigma_u } & 0 & 0 & 0 & 0 & 0 & 0 \\
\hline & -0.11 & -0.0712 & -0.147 & -0.114 & -0.173 & -0.233 \\
\hline \multirow[t]{2}{*}{ sigma_e } & $0.419 * * *$ & $0.316 * * *$ & $0.631 * * *$ & $0.541 * * *$ & $0.641 * * *$ & $1.070 * * *$ \\
\hline & -0.0852 & -0.0517 & -0.106 & -0.0928 & -0.146 & -0.188 \\
\hline Observations & 20 & 20 & 20 & 25 & 25 & 25 \\
\hline
\end{tabular}

Notes: Standard errors in parentheses. ${ }^{*} \mathrm{p}<0.1, * * \mathrm{p}<0.05, * * * \mathrm{p}<0.01$.

Continuation

\begin{tabular}{|l|l|l|l|l|l|l|}
\hline & SERV & SERV & SERV & CONGLO & CONGLO & CONGLO \\
\hline VARIABLES & BSI & BPI & BDI & BSI & BPI & BDI \\
\hline GEI & -0.0622 & $-0.307^{* * *}$ & $-0.301^{* * *}$ & -0.0481 & $-0.131^{* * *}$ & $-0.708^{* * *}$ \\
\hline & -0.0581 & -0.0837 & -0.0973 & -0.0554 & -0.0388 & -0.194 \\
\hline GSI & -0.0146 & -0.0684 & 0.156 & $-0.276^{* *}$ & $0.136^{*}$ & $-0.740^{*}$ \\
\hline & -0.121 & -0.245 & -0.216 & -0.11 & -0.0793 & -0.378 \\
\hline GPI & $0.512^{*}$ & -0.239 & $0.770^{*}$ & -0.81 & 0.00628 & -0.239 \\
\hline & -0.265 & -0.51 & -0.435 & -0.521 & -0.355 & -1.802 \\
\hline ROE & $-0.0172 *$ & 0.000509 & -0.00682 & -0.371 & 0.135 & $-1.557^{*}$ \\
\hline & -0.00978 & -0.0067 & -0.0113 & -0.262 & -0.158 & -0.802 \\
\hline MAEFF & -0.323 & -0.0338 & -0.0679 & $0.865^{* * *}$ & $-0.879^{* * *}$ & $-4.577^{* * *}$ \\
\hline & -0.404 & -0.629 & -0.931 & -0.265 & -0.182 & -0.942 \\
\hline WCM & -0.0162 & 0.0375 & 0.0188 & -0.0500 & $0.0544^{*}$ & $0.0261^{*}$ \\
\hline & -0.0679 & -0.0100 & -0.0140 & -0.0444 & -0.0298 & -0.0150 \\
\hline GROWTH & 0.026 & -0.311 & -1.116 & 1.435 & 0.992 & 0.587 \\
\hline & -0.416 & -0.789 & -1.214 & -0.882 & -0.606 & -2.982 \\
\hline BIG4 & 0.109 & 1.15 & 1.396 & $0.716^{* *}$ & $0.917 * * *$ & $3.923 * * *$ \\
\hline & -0.4 & -0.847 & -1.333 & -0.358 & -0.239 & -1.238 \\
\hline FAGE & 0.0177 & 0.0113 & -0.00396 & 0.0425 & $0.108^{* * *}$ & $0.213^{*}$ \\
\hline & -0.0172 & -0.0343 & -0.0548 & -0.0318 & -0.0221 & -0.111 \\
\hline IIAG & $21.80^{* * *}$ & $27.43^{*}$ & 19.63 & $16.97 * *$ & 7.317 & 28.84 \\
\hline & -6.404 & -16.62 & -12.65 & -7.679 & -4.935 & -24.93 \\
\hline Constant & -44.44 & 29.77 & -42.17 & $68.94 *$ & -10.83 & 72.55 \\
\hline
\end{tabular}




\begin{tabular}{|l|l|l|l|l|l|l|}
\hline & -28.49 & -46.71 & -45.34 & -40.59 & -27.86 & -140.9 \\
\hline sigma_u & $0.645^{* * *}$ & $1.513^{* * *}$ & $2.506^{* * *}$ & 0 & 0 & 0 \\
\hline & -0.161 & -0.39 & -0.486 & -0.11 & -0.0761 & -0.371 \\
\hline sigma_e & $0.976^{* * *}$ & $0.935 * * *$ & $1.625^{* * *}$ & $0.513^{* * *}$ & $0.359 * * *$ & $1.806^{* * *}$ \\
\hline & -0.0981 & -0.123 & -0.147 & -0.0849 & -0.0537 & -0.28 \\
\hline Observations & 100 & 100 & 100 & 25 & 25 & 25 \\
\hline
\end{tabular}

Notes: Standard errors in parentheses. ${ }^{*} \mathrm{p}<0.1, * * \mathrm{p}<0.05, * * * \mathrm{p}<0.01$.

Continuation

\begin{tabular}{|c|c|c|c|c|c|c|c|c|c|}
\hline & CONST & CONST & CONST & HELTH & HEALTH & HEALTH & ICT & ICT & ICT \\
\hline VARIABLES & BSI & BPI & BDI & BSI & BPI & BDI & BSI & BPI & $\mathrm{BDI}$ \\
\hline \multirow[t]{2}{*}{ GEI } & $-0.540 *$ & $0.464 *$ & 0.153 & $-0.148^{*}$ & -0.0186 & -0.244 & -0.0383 & $0.181 * *$ & $0.365^{* * * *}$ \\
\hline & -0.292 & -0.264 & -0.378 & -0.0826 & -0.0659 & -0.287 & -0.0272 & -0.0706 & -0.0853 \\
\hline \multirow[t]{2}{*}{ GSI } & 0.23 & -0.149 & -0.506 & 0.228 & -0.279 & -1.059 & $0.867 * * *$ & -0.256 & $1.498 * * *$ \\
\hline & -0.669 & -0.548 & -0.857 & -0.443 & -0.355 & -1.543 & -0.122 & -0.34 & -0.481 \\
\hline \multirow[t]{2}{*}{ GPI } & -0.651 & 1.136 & 0.855 & -0.159 & 0.371 & 1.221 & $-0.392 * * *$ & $1.198 * * *$ & -0.901 \\
\hline & -1.064 & -0.905 & -1.394 & -0.7 & -0.563 & -2.461 & -0.145 & -0.464 & -0.686 \\
\hline \multirow[t]{2}{*}{ ROE } & -0.205 & $-0.492 * *$ & $-1.340 * * *$ & $-1.658^{* * *}$ & $1.261^{*}$ & 4.11 & $0.0168^{*}$ & $0.251 * * *$ & 0.0103 \\
\hline & -0.264 & -0.205 & -0.505 & -0.813 & -0.653 & -2.837 & -0.00862 & -0.0457 & $\begin{array}{l}-0.0409 \\
\end{array}$ \\
\hline \multirow[t]{2}{*}{ MAEFF } & $3.730 * * *$ & $2.483^{* * *}$ & $6.958 * * *$ & $-3.781 * * *$ & $1.202 * *$ & $-9.253 * * *$ & $-2.424 * * *$ & 0.677 & -0.705 \\
\hline & -1.229 & -0.993 & -1.701 & -1.256 & -0.51 & -2.247 & -0.234 & -0.673 & -1.111 \\
\hline \multirow[t]{2}{*}{ WCM } & 0.0167 & $0.0412^{* * * *}$ & $-0.0758 * * *$ & $0.0424 * * *$ & 0.0288 & $-0.0425^{*}$ & $-0.0563 * * *$ & -0.0134 & 0.0446 \\
\hline & -0.0155 & -0.0122 & -0.0231 & -0.0147 & -0.0441 & -0.0219 & -0.0496 & -0.0101 & -0.0234 \\
\hline \multirow[t]{2}{*}{ GROWTH } & -0.871 & 1.392 & $4.953^{* *}$ & $1.960 * * *$ & $0.893 * * *$ & $4.176^{* * * *}$ & $8.060 * * *$ & 1.43 & 6.985 \\
\hline & -1.621 & -1.353 & -2.128 & -0.555 & -0.336 & -1.445 & -1.114 & -1.532 & -4.472 \\
\hline \multirow[t]{2}{*}{ BIG4 } & 4.53 & -5.575 & $-19.92 * * *$ & $1.643 * * *$ & 0.138 & $4.566^{* * * *}$ & $12.01 * * *$ & -15.52 & 19.47 \\
\hline & -5.295 & -4.477 & -6.985 & -0.582 & -0.314 & -1.477 & -2.781 & -9.957 & -12.27 \\
\hline \multirow[t]{2}{*}{ FAGE } & -0.413 & $0.639^{*}$ & $1.525 * * *$ & $0.0676^{* * * *}$ & $-0.0365 * * *$ & 0.00655 & $-0.0728 * * *$ & -0.00572 & $0.375^{* * * *}$ \\
\hline & -0.439 & -0.382 & -0.579 & -0.0235 & -0.0107 & -0.0464 & -0.01 & -0.0212 & -0.0438 \\
\hline \multirow[t]{2}{*}{ IIAG } & 24.13 & -51.49 & 39.41 & 12.35 & -5.199 & 12.41 & $11.67^{* * *}$ & $-37.79 *$ & 40.73 \\
\hline & -59.08 & -49.9 & -76.25 & -33.09 & -26.51 & -114.5 & -5.659 & -20.9 & -25.14 \\
\hline \multirow[t]{2}{*}{ Constant } & 79.38 & -112.4 & -135.5 & -1.035 & -20.07 & -65.7 & $-59.34 * * *$ & $-73.13 * * *$ & $-75.60 * *$ \\
\hline & -79.39 & -70.38 & -106 & -45.08 & -36.78 & -164.8 & -9.732 & -12.25 & -32.86 \\
\hline \multirow[t]{2}{*}{ sigma_u } & 0 & 0 & 0 & 0.28 & 0 & 0 & 0 & 0 & 0 \\
\hline & -0.155 & -0.121 & -0.207 & -0.223 & -0.108 & -1.375 & -0.0251 & -0.0371 & -0.116 \\
\hline \multirow[t]{2}{*}{ sigma_e } & $0.684 * * *$ & $0.473 * * *$ & $0.851 * * *$ & $0.622 * * *$ & $0.549 * * *$ & $2.370 * * *$ & $0.0885^{* * * *}$ & $0.130 * * *$ & $0.429 * * *$ \\
\hline & -0.117 & -0.0873 & -0.16 & -0.0923 & -0.0673 & -0.296 & -0.0183 & -0.0289 & -0.0862 \\
\hline Observations & 20 & 20 & 20 & 35 & 35 & 35 & 15 & 15 & 15 \\
\hline
\end{tabular}

Notes: Standard errors in parentheses. ${ }^{*} \mathrm{p}<0.1, * * \mathrm{p}<0.05, * * * \mathrm{p}<0.01$.

The study examined the effect of the dimensions of globalization on corporate governance indices of various industries in the economy, to identify which sector is highly influence by globalization using Tobit Model, this is presented in Table 9. From the analysis economic globalization (GEI) which is characterizes long distance flows of goods, capital and services as well as information and perceptions that accompany market exchanges, had significant influences on the sectors except agriculture and industrial goods sector. There is a high impact of economic globalization (GEI) on natural resources sector. Developing economies 
especially African is endowed with natural resources, the exploration of these resources requires huge capital investment. Africa is seen as a continent with cheaper labor but lack financial investment. Financial globalization as part of economic globalization is one of the areas used by the developed economies to invest in developing economies. FDI has been the main channel of investment by nations into other nations. Recent report shows that there is a drop in FDI inflows into developing economies especially Africa due to reduction in returns on investment. Globalization, is not inevitably driven by technological innovations, markets, and socio-political forces, as often depicted in popular writings, but is partly an outcome of policies from major global economy regulators, of which the Bretton Woods institutions-WB, the International Monetary Fund (IMF) and the World Trade Organization (WTO)-are the most important (Kapur, 1997). Developed countries which are labour-rich and capital-poor are rewarded with more access to foreign capital needed for investment and growth (Asongu and De Moor, 2016). This has been a different case in the past few years recording lower foreign investment in developing countries.

There was significant correlation between political globalization (GPI) and corporate governance sub-indices in all except conglomerate, construction and health sectors. Political globalization (GPI) is characterized by the diffusion of government policies. Good governance of a country affects the corporate governance of individual organizations in the country. Political globalization encompasses around government acceptance of foreign sovereign governmental influence and resources. Internationally oriented NGOs active in a country influence all sectors in an economy through exchange programs which has influence on structure, procedures and policies. Africa has received a number of supports from international oriented NGOs.

Social globalization (GSI) expresses the spread of ideas, information, images and people. Also it takes into account how policies and resources enable direct interactions among people living in different countries. The interaction can occur by the means of personal calls across borders. There is a relationship between social globalization (GSI) and corporate governance sub-indices in all the sectors except service, construction and health sectors. Internet connectivity of Africa to the rest of the world has influence information sharing to improve the living standards of the people. Consumer taste and preferences change due to continuous exposure to globalization. BSI, BPI and BDI are geared towards addressing individuals need in the shortest possible time. Globalization is not merely an economic phenomenon but also covers "technological developments, cultural exchanges, facilitated by ... freer trade [and] ... tourism and immigration, changes in the political landscape and ecological consequences" (Martens \& Raza, 2010). The influence of social globalization on good corporate governance mechanisms enables firms to continually be in business. Economic globalization and culture are "increasingly strategic issues that has to be faced and properly managed" (Granell, 2000).

There is a strong relationship between all the dimension of globalization and corporate governance indices in ICT sector. Informational globalization is meant to measure the actual flow of ideas, knowledge and images. Internet bandwidth measures the used capacity of international internet bandwidth and serves as a proxy for international digital information inand outflows. International patents, measured as the stock of patent applications made by 
non-residents, describe international flows of technology, scientific knowledge and related information (OECD, 2010). High technology exports describe flows of technological and scientific information. While international patents mainly describe an inflow of information, high technology exports mainly represent the outflow of information (Gygli et al., 2019).

\section{Conclusion}

This contribute to corporate governance literature by introducing the three dimension of globalization on corporate governance sub- indices namely board structure (BSI), board procedure (BPI) and board disclosure (BDI). Prior research focused on effect of financial globalization on corporate governance (min, 2013); financial development and corporate governance Gupta, Krishnamurti, \& Tourani-rad (2018), etc. significance of three dimension of globalization on corporate governance mechanisms is limited with industrial influence was lacking in most research. Using ordinary least square and Tobit model (instrumental model), we establish a relationship between economic, social, political with corporate governance sub-indices (BSI, BPI and BDI). Our findings show that there was significant relationship between all the three dimensions of globalization and board structure, board procedure and board disclosure. The influence of globalization sharpens the decision making process, and structures of organization in developing economies especially Africa. Attraction of investors depends on establishment of good corporate governance policies. Although past years Africa continent has enjoyed substantial FDI inflows, improper management and poor governance policies have caused a drop. There is a reduction in returns on investment for the past years and reduction in economic sustainable policy. Jan Schymik (2017) illustrates how globalization can be an important factor when it comes to explain the governance choices of firms. The model predicts that globalization toughens the competition for managerial talent such that firms allow for more managerial slack and create incentives with executive performance pay packages. Financial globalization, in combination with good macroeconomic policies and good domestic governance, appears to be conducive to growth.

Base on the above discoveries we recommend corporate governance rating for all firms in Africa must be put in place. Although some nations are having, for instance Nigeria and South Africa it should cut across all firms in Africa to monitor the activities of the various in industries. Good corporate governance principles of OCED (2015) must be adhered to by all listed firms in Africa. International Non- Profit Organizations (INGO's) must be well established to look into the governance structure of organizations in Sub-Sahara African countries and African continent as a whole.

Further research must be undertaken in all the sub region of African to have a full picture of effect of all the dimensions of globalization on corporate governance index so as to address the key issues hindering the speedily growth of the Africa continent.

\section{References}

Akbar, S., Poletti-hughes, J., El-faitouri, R., Zulfiqar, S., \& Shah, A. (2016). More on the Relationship between Corporate Governance and Firm Performance in the UK: Evidence from the Application of Generalized Method of Moments Estimation. Research in 
International Business and Finance. https://doi.org/10.1016/j.ribaf.2016.03.009

Asiedu, E. (2004). Policy reform and foreign direct investment in Africa: Absolute progress but relative decline. Development Policy Review, 22(1), 41-48.

https://doi.org/10.1111/j.1467-8659.2004.00237.x

Awio, G., Lawrence, S. R., \& Northcott, N. (2007). Community-led initiatives: reforms for better accountability?. Journal of Accounting and Organizational Change, 3(3), 209-226. https://doi.org/10.1108/18325910710820274

Ararat, M., Black, B. S., \& Yurtoglu, B. B. (2016). The Effect of Corporate Governance on Firm Value and Profitability: Time- Series Evidence from Turkey. Emerging Markets Review. https://doi.org/10.1016/j.ememar.2016.10.001

Berry, H. (2009). Globalization and the Rise of 'Economic Nationalism': Takeovers and Regulation within the European Union. International Journal of Economics and Business Research, 1(2), 234-251. https://doi.org/10.1504/IJEBR.2009.024022

Berle, A. A., \& Means, G. C. (1932). The Modern Corporation and Private Property. New York: Harcourt, Brace and World, Inc.

Bhagat, S., \& Bolton, B. (2019). Corporate governance and firm performance: The sequel Sanjai. Journal of Corporate Finance. https://doi.org/10.1016/j.jcorpfin.2019.04.006

Bordo, M., Eichengreen, B., \& Irwin, D. A. (1999). Is globalization today really different than globalization a hundred years ago? Working Paper, Cambridge: National Bureau of Economic Research 7915. https://doi.org/10.3386/w7195

Dagli, H., Eyuboglu, K., \& Ayaydin, H. (2012). Performance Evaluation of Corporate Governance Index in Turkey. Journal of Accounting and Finance, 12(2), 163-127.

Cornett, M. M., Marcus, A. J., Saunders, A., \& Tehranian, H. (2003). The impact of institutional ownership on corporate operating performance. Journal Bank. Finance, 31, 1771-1794. https://doi.org/10.1016/j.jbankfin.2006.08.006

Crawford, L., Extance, H., Helliar, C. V., \& Power, D. M. (2012). Operating segments: The usefulness of IFRS. Edinburgh: ICA

Crawford, L. (2017). Critical Perspectives on Accounting Exploring the emancipatory dimensions of globalisation: The struggle over IFRS8 and country-by-country reporting. Critical Perspectives on Accounting. https://doi.org/10.1016/j.cpa.2017.10.005

Cutting, B., \& Kouzim, A. (2002). The emerging patterns of power in corporate governance back to the future in improving corporate decision making. Journal of Managerial Psychology, 15(5), 477-507. https://doi.org/10.1108/02683940010337211

Farvaque, E., Refait-Alexandre, C., \& Saïdane, D. (2011). Corporate disclosure: a review of its (direct and indirect) benefits and costs. International Economics, 128, 5-31.

https://doi.org/10.1016/S2110-7017(13)60001-3 
Friedrichs, D. O., \& Friedrichs, J. (2002). The world bank and crimes of globalization: a case study. Globalization and Environmental Harm. Social Justice, 29(1/2), 13-36.

Fogarty, T. J., Hussein, M. E. A., \& Ketz, J. E. (1994). Political aspects of financial accounting standard-setting in the USA. Accounting, Auditing \& Accountability Journal, 7(4), 24-46. https://doi.org/10.1108/09513579410069830

Gallhofer, S., \& Haslam, J. (2006). The accounting-globalization interrelation: An overview with some reflections on the neglected dimension of emancipatory potentiality. Critical Perspectives on Accounting, 17(7), 903-934. https://doi.org/10.1016/j.cpa.2005.08.007

Gupta, K., Krishnamurti, C., \& Tourani-rad, A. (2018). Financial Development, Corporate Governance and Cost of Equity Capital. Journal of Contemporary Accounting \& Economics. https://doi.org/10.1016/j.jcae.2018.02.001

Gygli, S., Haelg, F., Potrafke, N., \& Sturm, J. (2019).The KOF Globalisation Index - revisited. The Review of International Organizations. https://doi.org/10.1007/s11558-019-09344-2

Hopper, T., Lassou, P., \& Soobaroyen, T. (2016). Critical Perspectives on Accounting Globalisation, accounting and developing countries. Critical Perspectives on Accounting, 1-24. https://doi.org/10.1016/j.cpa.2016.06.003

Ibrahim, Mo (2018). Ibrahim Index of African Governance, Mo Ibrahim Foundation.

IFRS Foundation (2013c). IASB - Who we are and what we do. London: IASB.

IFRS Foundation (2015a). Mission statement. [Online] Available: http://www.ifrs.org/About-us/Pages/IFRS-Foundation-and-IASB.aspx (Accessed July 2015).

Initiative (EITI) in sustainable resource development. [Online] Available: https://eiti.org/document/through-looking-glass-role-eiti-sustainable-resource-development Jhingan, M. L. (2010). The Economics of Development and Planning (14th Ed.). India: Vrinda Publications.

Kapur, G. (1997). Globalization and culture. Third Text, 11(39), 21-38. https://doi.org/10.1080/09528829708576670

Lehman, G. (2005). A critical perspective on the harmonization of accounting in a globalized world. Critical Perspectives on Accounting, 16(7), 975-992.

https://doi.org/10.1016/j.cpa.2003.06.004

Martens, P., \& Raza, M. (2010). Is globalisation sustainable?. Sustainability, 2(1), 280-293. https://doi.org/10.3390/su2010280

Mehlum, H., Moene, K., \& Torvik, R. (2006). Institutions and the resource curse. Economics Journal, 116, 1-20. https://doi.org/10.1111/j.1468-0297.2006.01045.x.

Min, B. S., \& Smyth, R. (2013). Corporate governance, globalization and firm productivity. Journal of World Business. https://doi.org/10.1016/j.jwb.2013.07.004 


\section{Macrothink}

Business and Economic Research

ISSN 2162-4860

2020, Vol. 10, No. 1

Moffat, P., \& Haralampieva, V. (2014). Through the looking glass of the Extractive Industries Transparency Initiative (EITI) in sustainable resource development, Law in transition, 4-1.

Mohamad, M. B. (2002), Globalization and Development Countries. [Online] Available: http://www.theglobalist.com

Munisi, G., \& Randøy, T. (2013). Corporate governance and company performance across Sub-Saharan African countries. Journal of Economics and Business, 70, 92-110. https://doi.org/10.1016/j.jeconbus.2013.08.003

OECD (2015). G20/OECD Principles of Corporate Governance. Paris, OECD Publishing. http://dx.doi.org/10.1787/9789264236882-en

Pillai, R., \& Al-malkawi, H. N. (2017). On the relationship between corporate governance and firm performance: Evidence from GCC countries. Research in International Business and Finance. https://doi.org/10.1016/j.ribaf.2017.07.110

Resource Governance (2010). Campaign for country-by-country reporting by companies: Action pack-new international financial reporting standards for extractives. London: Revenue Watch Institute.

Robertson, R. (1990). Mapping the global condition: globalization as the central concept. Theory Culture Society, 7, 15-30. https://doi.org/10.1177/026327690007002002

Ruparelia, R. (2016). The Evolution of Corporate Governance and Consequent Domestication in Kenya. International Journal of Business and Social Science, 7(5), 153-163.

Transparency International (2011). The 2011 corruption perceptions index measures the perceived levels of public sector corruption in 183 countries and territories around the world". [Online] Available: https://www.transparency.org/cpi2011

Wolf, M. (2003). Is globalization in danger?. The World Economy, 26(4), 393-411. https://doi.org/10.1111/1467-9701.00529

World Bank (1992). Governance and development. Washington DC: The World Bank

\section{Copyright Disclaimer}

Copyright for this article is retained by the author(s), with first publication rights granted to the journal.

This is an open-access article distributed under the terms and conditions of the Creative Commons Attribution license (http://creativecommons.org/licenses/by/3.0/). 